\title{
Cold exposure inhibits leptin secretion in vitro by a direct and non-specific action on adipose tissue
}

Roberto Peinó, Verónica Piñeiro, Oreste Gualillo, Carmen Menéndez, Juan Brenlla ${ }^{1}$, Xesús Casabiell, Carlos Diéguez ${ }^{2}$ and Felipe F Casanueva

Department of Medicine, Molecular Endocrinology Section, Santiago de Compostela University, Spain, ${ }^{1}$ Division of General Surgery, Hospital de Conxo, Complejo Hospitalario Universitario de Santiago, Spain and ${ }^{2}$ Department of Physiology, Santiago de Compostela University, Spain

(Correspondence should be addressed to F F Casanueva, PO Box 563,E-15780 Santiago de Compostela, Spain; E-mail: melage@usc.es)

\begin{abstract}
Objective: Leptin secretion is reduced by low temperatures in experimental animals, and this effect has been explained as an adaptive mechanism to cold environments. This study investigated the in vitro effects of cold exposure on human white adipose tissue.

Design: To understand whether the low temperature action is a direct or a mediated effect, leptin secretion was assessed in vitro in human omental adipose tissue incubated at varied temperatures, from 38 donors. As an internal control, the effect of reduced temperatures on in vitro GH secretion by GH3 cells was assessed.

Methods: Measurement of hormones secretion was carried out with an RIA, while human ob gene mRNA expression was assessed with reverse transcription PCR.

Results: Compared with the standard temperature of $37^{\circ} \mathrm{C}$, leptin secretion by human adipose tissue was significantly $(P<0.05)$ reduced when the incubations were carried out at $34.5^{\circ} \mathrm{C}(41 \%$ inhibition), and $32^{\circ} \mathrm{C}$ (68\% inhibition), with no parallel changes in the ob mRNA expression. At these reduced temperatures, glucocorticoid-mediated leptin secretion was well preserved. When the effect of reduced temperatures was assessed on in vitro $\mathrm{GH}$ secretion, a superimposable reduction was observed.

Conclusions: These results indicate: (i) that low temperatures reduce leptin secretion by acting directly on the adipose tissue and (ii) that the similar reduction in a hormone unrelated to energy metabolism, such as GH, suggests that the observed reduction is a mechanical perturbation of leptin secretion, which may be devoid of physiological implications.
\end{abstract}

European Journal of Endocrinology 142 195-199

\section{Introduction}

Animals living in extreme climates show a marked seasonal variation in both food intake and energy expenditure, as a response to the changing metabolic requirements imposed by differences in environmental temperature $(1-5)$. These two variables are under strict control by the product of the ob gene, leptin, an adipocyte-secreted hormone that acts on hypothalamic centres and regulates the energy balance by determining changes in both food intake and energy expenditure (6-8). Physiologically, leptin plasma concentrations reflect the adipose tissue deposits $(9,10)$ and appear to be negatively regulated by fasting (8), protein kinase $\mathrm{C}(11)$, androgens $(12)$ and $\beta$-adrenergic agonists (13), whereas feeding $(8,14)$, oestrogens (15), glucocorticoids $(15,16)$ and insulin $(17)$ act by stimulating both ob gene expression and leptin secretion.
Furthermore, leptin is implicated in physiological states that require variations in energy expenditure and energy intake like exercise $(18,19)$ or reproduction (20-25).

It has been shown that cold exposure reduces circulating leptin levels in rodents (26-28), suggesting that this hormone may participate in the adaptive mechanisms triggered by variations in external temperature. The inhibitory effect of low temperatures has been explained as the result of an increase in the adrenergic tone induced by exposure to cold temperatures, which would in turn act through the $\beta-3$ receptors present in the adipose tissue inducing a reduction in the expression of the leptin mRNA (26). However, the exact mechanism of leptin reduction by cold exposure is not fully understood, and it has not been elucidated whether it is a direct or indirect action upon the adipose tissue; nor is its physiological meaning known. 
In this work, the action of low temperature exposure on leptin secretion has been assessed in human omental adipose tissue in vitro. The aims of the study were: (i) to evaluate whether the action of low temperatures was also observable for human leptin; (ii) to determine whether that action was exerted directly on the adipose tissue, or mediated by other in vivo factors; and (iii) to determine whether it was a physiological action or merely the result of a physical perturbation.

\section{Materials and methods}

\section{Subjects}

Omental adipose tissue was obtained from 38 non-obese patients $(25$ male, 13 female, aged $63.31 \pm 2.61$ years, and with a body mass index of $27.02 \pm 0.61 \mathrm{~kg} / \mathrm{m}^{2}$ ) during elective abdominal surgery. Patients were taking no drugs, nor were they under antibiotic therapy. The study was approved by the Hospital Ethical Committee and each participating subject provided informed consent.

\section{Cell and tissue cultures}

Organ adipose tissue culture was performed as described $(11,12,15)$. In brief, excised adipose tissue was immediately transported to the laboratory in ice-cold Krebs-Ringer-Hepes (KRH) buffer (in mmol/l: $\mathrm{NaCl}$, $125 ; \mathrm{KCl}, 5 ; \mathrm{MgSO}_{4}, 1.2 ; \mathrm{CaCl}_{2}, 2 ; \mathrm{KH}_{2} \mathrm{PO}_{4}, 1.2$; glucose, 6; Hepes, 25; pH 7.4). After removing blood vessels and conjunctive tissue, adipose tissue was washed with sterile KRH and cut into small pieces with sharp scissors. Tissue fragments were placed in six-well multiwell dishes (300-400 mg adipose tissue/ well) containing $2.5 \mathrm{ml}$ Dulbecco's modified Eagle's medium plus $0.5 \%$ fetal calf serum, supplemented with penicillin $(100 \mathrm{U} / \mathrm{ml})$ and streptomycin sulphate $(100 \mu \mathrm{g} / \mathrm{ml})$. GH3 cells were cultured essentially as described $(29,30)$. As their growth rate was dependent on temperature, parallel incubations were carried out for both growth hormone (GH) determination and cell counting. After a pre-incubation period of $1 \mathrm{~h}$ at $37^{\circ} \mathrm{C}$ in a humidified atmosphere of $95 \%$ air-5\% $\mathrm{CO}_{2}$, samples were either maintained in the same incubator as internal controls, or transferred to a second incubator in parallel, pre-equilibrated at the required temperature with a similar atmosphere. Unless specifically indicated, all drugs and reagents were from Sigma, St Louis, MO, USA.

\section{Measurement of hormone secretion}

For each tested temperature, the adipose tissue from a given subject was independently incubated in triplicate and the medium was collected and analysed at 24 and $48 \mathrm{~h}$ to obtain the integrated secretion (area under the curve, AUC) at $48 \mathrm{~h}(15,31)$. Samples were stored at $-20{ }^{\circ} \mathrm{C}$ until assayed for leptin secretion. Leptin levels were measured in duplicate by RIA using commercial kits (Human Leptin RIA; Linco Research Inc., St Charles, MO, USA). The limit of sensitivity was $0.5 \mu \mathrm{g} / \mathrm{l}$, the intra-assay coefficient of variation was $8.3 \%$, and the inter-assay coefficient of variation $6.2 \%$. GH levels were determined by RIA using reagents provided by the National Hormone and Pituitary Program of NIDDK (Bethesda, MD, USA), as previously described $(29,30)$.

\section{RNA preparation and reverse transcription PCR (RT-PCR)}

Total RNA was isolated from frozen adipose tissues after $48 \mathrm{~h}$ incubation by the acidic phenol/chloroform method of Chomczynski \& Sacchi (32). Tissues (about $100 \mathrm{mg}$ ) were homogenised using a Polytron homogeniser (Kinematica AG, Littau, CH) and recovery of total RNA was measured with a spectrophotometer (Beckman DU62; Beckman Instruments, Inc., Fullerton, CA, USA) at $260 \mathrm{~nm}$. One microgram total RNA was used to perform RT-PCR. cDNAs were synthesised using 200 units of Moloney murine leukaemia reverse transcriptase (Gibco-BRL, Eggenstein, Germany) and random hexamers (Promega, Madison, WI, USA). The reaction, in a final volume of $30 \mu \mathrm{l}$, was carried out at $37^{\circ} \mathrm{C}$ for $50 \mathrm{~min}$, $42^{\circ} \mathrm{C}$ for $15 \mathrm{~min}$ and $95^{\circ} \mathrm{C}$ for $5 \mathrm{~min}$ in first-strand buffer (Gibco Y00146) containing 10 U ribonuclease inhibitor. The cDNA was amplified using human specific primers for the ob gene (upstream primer: $5^{\prime}$-ATGCATTGGGGAACC CTGTGCGG-3'; downstream primer: 5'-TGAGGTCCAGC TGCCACAGCATG- $\left.3^{\prime}\right)$. The cDNAs were also amplified using human HPRT (hypoxanthine-guanine phosphoribosyl transferase) primers (downstream primer: 5'AGCAAGACGTTCAGTCCTGTC-3'; upstream primer: 5'CAGTCCCAGCGTCGTGATTA-3'), as a quality and quantity control. PCR was performed using $0.2 \mathrm{mmol} / \mathrm{l} \mathrm{dNTPs}$ (Promega), $1.25 \mathrm{U}$ Taq-DNA polymerase (Gibco-BRL), $5 \mu \mathrm{l}$ $10 \times \mathrm{PCR}$ buffer $(18.6 \mathrm{mmol} / \mathrm{l}$ Tris- $\mathrm{HCl}, 45.9 \mathrm{mmol} / \mathrm{l} \mathrm{KCl}$, $3 \mathrm{mmol} / \mathrm{l} \mathrm{MgCl}_{2}$ ) in a total volume of $50 \mu \mathrm{l}$. PCR was carried out on an Eppendorf Master Cycler gradient thermal cycler (Eppendorf GmbH, Hamburg, Germany) under the following conditions: $94^{\circ} \mathrm{C}$ for $1 \mathrm{~min}$ for denaturation, $60^{\circ} \mathrm{C}$ for $1 \mathrm{~min}$ for annealing and $72^{\circ} \mathrm{C}$ for $1 \mathrm{~min}$ for extension ( 35 cycles), with an additional elongation cycle at $72{ }^{\circ} \mathrm{C}$ for $10 \mathrm{~min}$. PCR products were separated on a $2 \%$ agarose gel and stained with ethidium bromide to visualise the resulting bands. Gels were examined under UV light and quantitated with a GelDoc 1000 Documentation System (BioRad Laboratories, Mississauga, Ontario, Canada).

\section{Statistic analysis}

Leptin (ng/g tissue) and GH secretion values (ng/10 cells) were expressed as the AUC at $48 \mathrm{~h}$ (trapezoidal 
method) and plotted as the percentage over controls. Comparisons were made by the unpaired $t$-test. Values of $P<0.05$ were considered significant.

\section{Results}

The effect of different incubation temperatures on leptin secretion was assessed in vitro using an adipose tissue organ culture system recently described by our group $(11,12,15)$. As no gender-based differences were observed for the effect of temperature on leptin secretion, values from both male and female donors were pooled for the analysis. The integrated in vitro leptin secretion (expressed as AUC after $48 \mathrm{~h}$ incubation in $\mathrm{ng} / \mathrm{g}$ of tissue per $24 \mathrm{~h}$ ) by human omental adipose tissue showed a marked dependence on the incubation temperature (Fig. 1A). Leptin secretion was significantly reduced at $32{ }^{\circ} \mathrm{C}(68 \%$ inhibition, $P=0.0050, n=10)$ and $34.5^{\circ} \mathrm{C}(41 \%$ inhibition, $P=0.0257, n=15)$, while no statistically significant differences in the spontaneous leptin secretion were found between cells incubated at $39.5^{\circ} \mathrm{C}$ and controls $(P=0.5201, n=13)$. In samples derived from women, the ability of the adipose cells to respond to a challenge with $1 \mu \mathrm{mol} / \mathrm{l}$ dexamethasone with a clear-cut increase of leptin secretion (15) was well preserved at 32 and $34.5^{\circ} \mathrm{C}$ (data not shown), suggesting that the tissue remained viable and that the mechanisms that regulate leptin secretion were still acting at the reduced temperatures. On the contrary, the response to dexamethasone was suppressed at $39.5^{\circ} \mathrm{C}$, a temperature that was probably high enough to induce a certain degree of metabolic perturbation in cells on prolonged incubations (data not shown).

The specificity of this temperature effect was evaluated using as a parallel control experiments in cultures of $\mathrm{GH} 3$ cells, a line of pituitary-derived cells that constitutively secretes $\mathrm{GH}$ in vitro. As Fig. 1B shows, the spontaneous GH secretion by GH3 cells also showed a decrease when the temperature was reduced during the $24 \mathrm{~h}$ incubation, the overall picture being quite similar to the one obtained for leptin secretion, with a $64 \%$ reduction in $\mathrm{GH}$ secretion at $32{ }^{\circ} \mathrm{C}(P=0.0489$, $n=4)$. The regression lines showed that the effects of temperature on the secretion rate for both adipose tissue and GH3 cells were superimposable (Fig.1C).

RT-PCR of human adipose tissue cDNA yielded a band with the expected size of $487 \mathrm{bp}$ (Fig. 2). Densitometric analysis of detected amplimers showed no variation in ob gene expression when the samples were incubated at temperatures outside the physiological range. In particular, no significant differences were observed in leptin gene expression by samples incubated at $39.5^{\circ} \mathrm{C}$ (lanes 2 and 4 ) or $34.5^{\circ} \mathrm{C}$ (lanes 6 and 8) in comparison with their respective controls at $37^{\circ} \mathrm{C}$ (lanes 1, 3, 5 and 7). These results suggest that the temperature-related differences observed in leptin secretion levels are primarily related to a modification in the

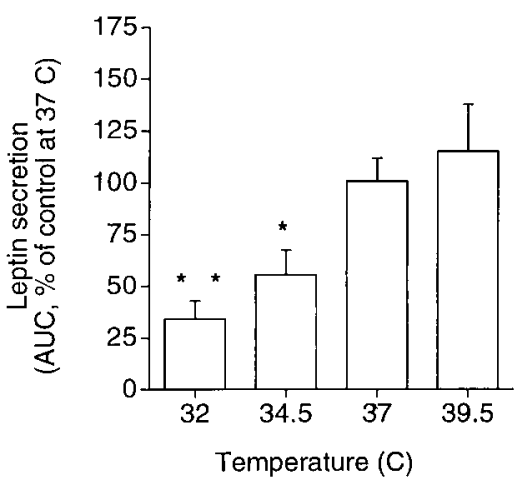

A

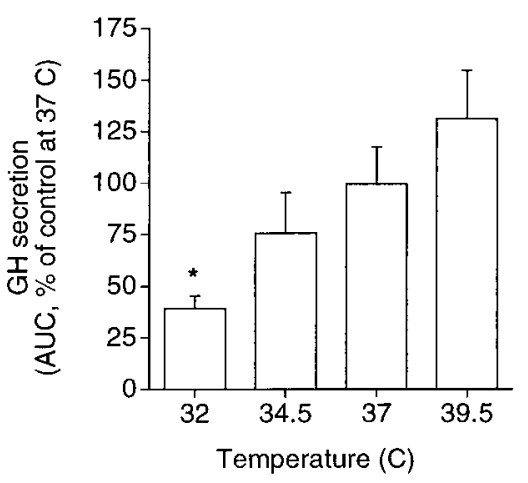

B

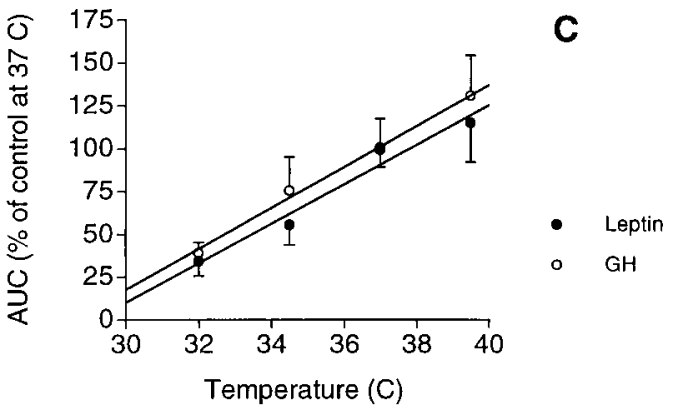

Figure 1 (A) Effect of different incubation temperatures on leptin secretion by human omental adipose tissue in vitro. (B) Effect of different incubation temperatures on $\mathrm{GH}$ secretion by $\mathrm{GH} 3$ cells in vitro. (C) Regression analysis of secretion vs incubation temperature for both adipose tissue and GH3 cells. Data (mean \pm S.E.M. of the AUC at $48 \mathrm{~h}$ ) are expressed as the percentage over the control $\left(37^{\circ} \mathrm{C}\right)$ values. ${ }^{*} P<0.05 ;{ }^{* *} P<0.005$.

secretion rate of mature protein and not to a change in the expression of the ob gene.

\section{Discussion}

Exposure of experimental animals to cold environments results in a decrease of circulating leptin (26-28). For animals living in zones with large seasonal temperature variations this may represent an adaptive mechanism for maximising the size of fat deposits when the 


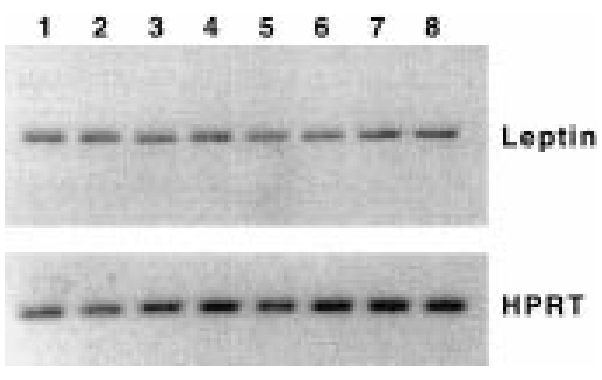

Figure 2 Agarose gel (2\%) stained with ethidium bromide showing PCR products obtained using specific primers for the ob gene. No differences were observed in leptin gene expression from human adipose tissue after $48 \mathrm{~h}$ incubation at $39.5^{\circ} \mathrm{C}$ (lanes 2 and 4 ) and $34.5^{\circ} \mathrm{C}$ (lanes 6 and 8 ) vs their respective controls at $37^{\circ} \mathrm{C}$ (lanes $1,3,5$ and 7 ). Quality and quantity controls were obtained by performing parallel PCR of the housekeeping gene HPRT (139 bp product).

environment temperature begins to decline, in order to survive the cold season. As the adrenergic tone increases in vivo when the temperature is lowered, it is possible that an increased stimulation of the adipocytespecific $\beta 3$-adrenergic receptors, with the ensuing increase of the intracellular cAMP levels, which would in turn inhibit the ob mRNA expression, may constitute the physiological basis for this leptin reduction. In fact, it has been reported that this is the case for mice (33) and rats (26), although not for other rodents, such as the Djungarian hamster (34). Despite the fact that in homeotherm animals the core temperature of the body is maintained during exposure to low environmental temperatures, a large fraction of the total mass of adipose tissue is localised directly under the skin, acting as insulation to avoid excessive heat loss. This anatomical localisation, together with the inherent low vascularisation of adipose tissue, causes the temperature in the subcutaneous fat deposits to fall several degrees below the core temperature upon exposure to cold. However, the possibility of a direct effect of low temperature on the adipose tissue itself has not been addressed experimentally.

In an attempt to clarify this issue, a previously validated in vitro organ culture system was used to test directly the effect of different temperatures on the rate of leptin secretion. As a control, we checked GH secretion by GH3 cells maintained under the same temperature conditions. The results show that the secretion of leptin by human omental adipose tissue in vitro is strongly temperature dependent, being reduced almost to a half when the temperature of the adipose tissue is lowered by as little as $2.5^{\circ} \mathrm{C}$. This is the first demonstration that cold also reduces leptin secretion in humans and that the effect is a direct action on the adipose tissue. However, as no temperature-dependent modification on the ob mRNA levels was detected by RT-PCR, the effect of temperature does not appear to be part of a long-term physiological regulatory system of leptin secretion, but rather a non-specific effect of temperature on the secretory pathway. Both the intracellular transport of proteins to the cell surface and the fusion of secretory granules with the plasma membrane are temperature dependent $(35,36)$. In fact, the vesicular forward transport events that take place along all the steps of the secretory pathway can be completely blocked at $20^{\circ} \mathrm{C}$. In agreement with this interpretation, the secretion of $\mathrm{GH}$ by $\mathrm{GH} 3$ cells was also found to be temperature dependent, and was reduced by a similar extent when they were incubated at the same temperatures as the adipose tissue samples. These results point towards the interpretation that the low temperature effect on leptin secretion is a physical or mechanical effect, casting doubts on its physiological meaning. In fact, from a teleological explanation, the reduction of plasma leptin at the onset of the cold season would have a positive effect, increasing food intake, but also a negative one, reducing thermogenesis. In the animal under hibernation, a low leptin level may help to reduce energy expenditure, but the increase in appetite is useless.

In conclusion, leptin secretion by human omental adipose tissue in vitro was inhibited by reducing the temperature of the adipose tissue itself, probably by a reduction in the overall efficiency of the secretory pathway. Whether this represents a physiological regulatory mechanism or merely a non-specific physical or mechanical change remains to be ascertained.

\section{Acknowledgements}

This work was supported by grants from Xunta de Galicia and by the Fondo de Investigación Sanitaria, Spanish Ministry of Health. The expert technical assistance of Ms Mary Lage is acknowledged. OG is the recipient of a TMR-30 Marie Curie Research Training Grant, Program IV Framework Program of RTD; Contract \# ERBFMBI-CT 98-3368, from the European Commission.

\section{References}

1 Ho HS \& Edwards WP. The effect of environmental temperature and average dose rate of microwave radiation on the oxygenconsumption rate of mice. Radiation and Environment Biophysics $197916325-338$.

2 Trayhurn P \& James WP. Thermoregulation and non-shivering thermogenesis in the genetically obese $(\mathrm{ob} / \mathrm{ob})$ mouse. Pflugers Archives 1978373 189-193.

3 Trenkle A. Relation of hormonal variations to nutritional studies and metabolism of ruminants. Journal of Dairy Science 197861 281-293.

4 Hill JR \& Rahimtulla KA. Heat balance and the metabolic rate of new-born babies in relation to environmental temperature; and the effect of age and of weight on basal metabolic rate. Journal of Physiology $1965180239-265$.

5 Grausz JP. The effects of environmental temperature changes on the metabolic rate of newborn babies. Acta Paediatrica Scandinavica 196857 98-104. 
6 Zhang Y, Proenca R, Maffei M, Barone M, Leopold L \& Friedman JM. Positional cloning of the mouse obese gene and its human homologue. Nature 1994372 425-432.

7 Masuzaki H, Ogawa Y, Hosoda K, Kiyawaki T, Hanaoka I, Hiraoka J et al. Glucocorticoid regulation of leptin synthesis and secretion in humans: elevated plasma leptin levels in Cushing's syndrome. Journal of Clinical Endocrinology and Metabolism 1997822542 2547.

8 Ahima RS, Prabakaran D, Mantzoros C, Qu D, Lowell B, Manatos Flier E et al. Role of leptin in the neuroendocrine response to fasting. Nature 1996382 250-252.

9 Havel PJ, Kasim Karakas S, Mueller W, Johnson PR, Gingerich RL \& Stern JS. Relationship of plasma leptin to plasma insulin and adiposity in normal weight and overweight women: effects of dietary fat content and sustained weight loss. Journal of Clinical Endocrinology and Metabolism 199681 4406-4413.

10 Maffei M, Halaas J, Ravussin E, Pratley RE, Lee GH, Zhang Y et al. Leptin levels in human and rodent: measurement of plasma leptin and ob RNA in obese and weight-reduced subjects. Nature Medicine 19951 1155-1161.

11 Piñeiro V, Casabiell X, Peino R, Garcia-Vallejo L, Dieguez C \& Casanueva FF. PMA inhibits both spontaneous and glucocorticoid-mediated leptin secretion by human omental adipose tissue explants in vitro. Biochemical and Biophysical Research Communications 1998252 345-347.

12 Piñeiro V, Casabiell X, Peino R, Lage M, Camiña JP, Menendez C et al. Gender differences in androgen-mediated leptin secretion by human omental adipose tissue in vitro: Dihydrotestosterone, stanozolol, androstenedione and dehydroepiandrosterone-S inhibit leptin release in women but not in men. Journal of Endocrinology $1999160425-432$.

13 Mantzoros CS, Qu D, Frederich RC, Susulic BB, Lowell E, Maratos Flier E et al. Activation of beta(3) adrenergic receptors suppresses leptin expression and mediates a leptin-independent inhibition of food intake in mice. Diabetes 199645 909-914.

14 Caro JF, Sinha MK, Kolaczynski JW, Zhang PL \& Considine RV. Leptin: the tale of an obesity gene. Diabetes 199645 1455-1462.

15 Casabiell X, Piñeiro V, Peinó R, Lage M, Camiña JP, Gallego R et al. Gender differences in both spontaneous and stimulated leptin secretion by human omental adipose tissue in vitro: Dexamethasone and estradiol stimulate leptin release in women but not in men samples. Journal of Clinical Endocrinology and Metabolism $1998832149-2155$.

16 De Vos P, Saladin R, Auwerx J \& Staels B. Induction of ob gene expression by corticosteroids is accompanied by body weight loss and reduced food intake. Journal of Biological Chemistry 1995270 15958-15961.

17 Hardie LJ, Guilhot N \& Trayhurn P. Regulation of leptin production in cultured mature white adipocytes. Hormones and Metabolism Research 199628 685-689.

18 Hickey MS, Considine RV, Israel RG, Mahar TR, McCammou MR, Tyndall GL et al. Leptin is related to body fat content in male distance runners. American Journal of Physiology 1996271 E938-E940.

19 Leal-Cerro A, García-Luna P, Astorga R, Panejo J, Peinó R, Diéguez $\mathrm{C}$ et al. Serum leptin levels in male marathon athletes before and after the marathon run. Journal of Clinical Endocrinology and Metabolism 199883 2376-2379.

20 Ahima RS, Dushay J, Flier SN, Prabakaran D \& Flier JS. Leptin accelerates the onset of puberty in normal female mice. Journal of Clinical Investigation 199799 391-395.

21 Chehab FF, Mounzih K, Lu R \& Lim ME. Early onset of reproductive function in normal female mice treated with leptin. Science 19971997 88-90.
22 Chehab FF. The reproductive side of leptin. Nature Medicine 1997 3 952-953.

23 Señaris R, Garcia-Caballero T, Casabiell X, Gallego R, Castro R, Considine RV et al. Synthesis of leptin in human placenta. Endocrinology 1997138 4501-4504.

24 Casabiell X, Piñeiro V, Tomé MA, Peinó R, Diéguez C \& Casanueva FF. Presence of leptin in colostrum and/or breast milk from lactating mothers: a potential role in the regulation of neonatal food intake. Journal of Clinical Endocrinology and Metabolism 199782 4270-4273.

25 Tome M, Lage M, Camiña J, Garcia-Mayor R, Dieguez C \& Casanueva FF. Gender-based differences in serum leptin levels from umbilical cord blood at delivery. European Journal of Endocrinology 1997137 655-658.

26 Trayhurn P, Duncan JS \& Rayner DV. Acute cold-induced suppression of ob (obese) gene expression in white adipose tissue of mice: mediation by the sympathetic system. Biochemical Journal $1995311729-733$.

27 MacDougald OA, Hwang CS, Fan H \& Lane MD. Regulated expression of the obese gene product (leptin) in white adipose tissue and 3T3-L1 adipocytes. Proceedings of the National Academy of Sciences of the USA $1995929034-9037$.

28 Hardie LJ, Rayner DV, Holmes S \& Trayhurn P. Circulating leptin levels are modulated by fasting, cold exposure and insulin administration in lean but not Zucker (fa/fa) rats as measured by ELISA. Biochemical and Biophysical Research Communications 1996223 660-665.

29 Pérez FR, Casabiell X, Camiña JP, Zugaza JL \& Casanueva FF. cis-Unsaturated free fatty acids block growth hormone and prolactin secretion in thyrotropin-releasing hormone-stimulated GH3 cells by perturbing the function of plasma membrane integral proteins. Endocrinology 1997138 264272.

30 Pérez FR, Camiña JP, Zugaza JL, Lage M, Casabiell X \& Casanueva FF. cis-FFA do not alter membrane depolarization but block $\mathrm{Ca}^{2+}$ influx and $\mathrm{GH}$ secretion in KCl-stimulated somatotroph cells. Suggestion for a direct cis-FFA perturbation of the $\mathrm{Ca}^{2+}$ channel opening. Biochimica et Biophysica Acta 1997 1329 269-277.

31 Barr V, Malide D, Zarnowski M, Taylor S \& Cushman S. Insulin stimulates both leptin secretion and production by rat white adipose tissue. Endocrinology 138 4463-4472.

32 Chomczynski P \& Sacchi N. 1987 Single-step method of RNA isolation by acid guanidinium thiocyanate-phenol-chloroform extraction. Analytical Biochemistry 1997162 156-159.

33 Moinat M, Deng C, Muzzin P, Assimacopoulos I, Seidoux JAG, Dulloo et al. Modulation of obese gene expression in rat brown and white adipose tissues. FEBS Letters 1995373 131-134.

34 Klingenspor M, Dickopp A, Heldmaier G \& Klaus S. Short photoperiod reduces leptin gene expression in white and brown adipose tissue of Djungarian hamsters. FEBS Letters 1996399 290-294.

35 Hirao Y \& Yanagimachi R. Temperature dependence of spermegg fusion and post-fusion events in hamster fertilization. Journal of Experimental Zoology 1978205 433-437.

36 Berlin RD, Fera JP \& Pfeiffer JR. Reversible phagocytosis in rabbit polymorphonuclear leukocytes. Journal of Clinical Investigation $1979631137-1144$.

Received 17 May 1999

Accepted 28 September 1999 